\title{
In Vitro Metabolism Effect on Genotoxicity and Antigenotoxicity of Agaricus blazei Organics and Aqueous Extracts by the Comet Assay
}

\author{
Marilanda Ferreira Bellini ${ }^{1}$, Ana Paula Terezan², Lúcia Regina Ribeiro ${ }^{3}$ and \\ Mário Sérgio Mantovani ${ }^{1, *}$ \\ ${ }^{1}$ Departamento de Biologia Geral, Universidade Estadual de Londrina, Londrina-PR-Brazil \\ ${ }^{2}$ Departamento de Química, Universidade Federal de São Carlos-UFSCar, São Carlos-SP-Brazil \\ ${ }^{3}$ Departamento de Patologia, UNESP, Botucatu-SP-Brazil
}

Received August 15, 2005; accepted January 10, 2006

\begin{abstract}
Summary There is high interest in the natural products properties due to their use in popular medicine. Agaricus blazei Murrill ss. Heinem. (Ab) is native to Brazil and has been widely disseminated because its medicinal properties. In the present study, the genotoxic and antigenotoxic potential of $\mathrm{Ab}$ extracts were investigated using the comet assay. The cells utilized were the non drug-metabolizing line CHO-k1 (Chinese hamster ovary) and the drug-metabolizing line HTC (rat hepatoma). Cells were treated for $3 \mathrm{~h}$ in the absence of fetal bovain serum (FBS) with methanolic, hexanic and $n$-butanolic extracts at $50 \mu \mathrm{g} / \mathrm{ml}$ and $0.75 \%$ aqueous extract to test for genotoxicity. Antigenotoxic effects of extracts were determined in cells exposed to the DNA damage inducing agent ethyl methanesulfonate under simultaneous or simultaneous with $1 \mathrm{~h}$ pre-incubation conditions. The extracts did not show genotoxicity in HTC, while they were genotoxic in CHO-k1. No antigenotoxic effect was observed with any extract under any condition. These results demonstrate that the metabolism in presence or in absence has a direct influence on the genotoxicity of these extracts.
\end{abstract}

Key words Agaricus blazei, Genotoxicity, Antigenotoxicity, Comet assay, Metabolism.

Many basidiomycetes species are valuable as genetic information sources that can be utilized in biotechnology for the new foods or drugs development. Various edible mushrooms have been studied for their nutritional and medicinal properties (Mizuno 1995a).

Agaricus blazei (Agaricaceae, Agaricomycetideae) was discovered in Piedade-SP, in the 1970s by an amateur botanist living in that region, Takatoshi Furomoto, who demonstrated its medicinal properties. Since he did not have the appropriate facilities to study it, he sent samples of the mushroom to research centers in Japan and Argentina. It was cultivated artificially in Japan and studied extensively at the Iwade Mushroom Institute in Mie. There, it also became known as Himmematsutake, Mushroom of the Gods, Sun Mushroom and Princess Kawaritake, and in 1996, Japanese investigators met and gave it the definitive name Agaricus blazei Murrill. However, due to the new classification, it then became known as Agaricus blazei Murrill ss. Heinem. (Wasser et al. 2002).

$A$. blazei is frequently consumed as food or tea in different parts of the world, because of its medicinal effects. It is believed to fight physical and emotional stress, stimulate immunity, improve the quality of life in diabetics, reduce cholesterol, prevent osteoporosis and ulcers, treat circulatory and digestive problems, and act as an antioxidant with possible anticarcinogenic and antimutagenic effects. Studies have shown it to have antitumor activity (Mizuno 1995b), anticlastogenic/antimutagenic effects in vivo (Delmanto et al. 2001) as well as in vitro (Menoli et al. 2001, Oliveira et al. 2002, Luiz et al. 2003b, Bellini et al. 2003, Machado et al. 2005), and an anticarcinogenic effect

* Corresponding author, e-mail: biomsm@uel.br 
(Takeda et al. 2000).

Due to the large consumption of this basidiomycete in popular medicine, more data is needed regarding its mechanisms of action. Therefore, the aim of this study was to determine the genotoxicity and antigenotoxicity of organic (methanolic, hexanic and $n$-butanolic) and aqueous extracts of Agaricus blazei in cultured mammalian cells, where genetic damage was measured by the comet assay in the absence of drug metabolism (CHO-k1 Chinese hamster ovarian cells) and presence of drug metabolism (HTC rat hepatoma cells).

\section{Materials and methods}

\section{Preparation of Ab extracts}

The methanolic (ME), hexanic (HE) and $n$-butanolic (BE) extracts of Agaricus blazei Murrill ss. Heinem (Ab), strain 99/26, were kindly provided by Dr. Edson Rodrigues Filho of the Chemistry Department, Universidade Federal de São Carlos.

The mushroom fruiting body $(896.90 \mathrm{~g})$ was extracted with dichloromethane/hexane $(50: 50)$, dichloromethane (100), dichloromethane/methanol (50:50), methanol (100) and methanol/water $(50: 50)$. The hydroalcoholic extract obtained was first partitioned with dichloromethane, and the organic phase was concentrated and partitioned with methanol and hexane, yielding a hexane fraction $(\mathrm{HF} / 7.02 \mathrm{~g})$ and methanol fraction $(\mathrm{MF} / 11.80 \mathrm{~g})$. Subsequently, the hydroalcoholic extract was partitioned with ethyl acetate and $n$-butanol, respectively, yielding from the final partition an aqueous fraction $(\mathrm{AF} / 55.00 \mathrm{~g})$ and $n$-butanol fraction $(\mathrm{BF} / 16.93 \mathrm{~g})$. These were dissolved in DMSO (dimethyl sulfoxide, Mallinckrodt) at a concentration of $5 \mathrm{mg} / \mathrm{ml}$. Aliquots were stored frozen until use time. The extracts final concentration in cultures was $50 \mu \mathrm{g} / \mathrm{ml}$.

The aqueous extract (AE) was prepared by adding $20 \mathrm{~g}$ of powdered Ab (Culture CollectionDepartment of Crop Production, Botucatu Campus, UNESP, Exsiccata strain ABL 99/26; June 12, 2001, Augusto F. da Eira) to $200 \mathrm{ml}$ of deionized water at $25^{\circ} \mathrm{C}$. The mixture was shaken continuously for $2 \mathrm{~h}$ in the dark. It was then passed though a double layer of filter paper, followed by sterile filtration through a $0.22-\mu \mathrm{m}$ cellulose acetate membrane. Aliquots of $\mathrm{AE}$ were kept frozen until time of use. The final concentration of AE in cultures was $0.75 \%$.

\section{DNA damage-inducing agent}

DNA damage was induced with the direct-acting alkylating agent ethyl methanesulfonate (EMS, Acros). A stock solution was prepared in sterile phosphate buffered saline (PBS), $\mathrm{Ca}^{2+}$ and $\mathrm{Mg}^{2+}$ free, $\mathrm{pH} 7.4$, and used at a final concentration of $155 \mu \mathrm{g} / \mathrm{ml}$ in cultures.

\section{Cell lines and treatments}

The Chinese hamster ovarian cell line CHO-k1 (wild-type) used in this study was provided by Dr. Catarina S. Takahashi of the Mutagenesis Laboratory in the Faculdade de Medicina de Ribeirão Preto, Universidade de São Paulo (USP). The rat hepatoma cell line (HTC) was acquired from the Rio de Janeiro Cell Bank. Cells were grown in DMEM/F-12 medium (Gibco) supplemented with $10 \%$ fetal bovine serum (FBS; Gibco). The cells were cultivated as monolayers in $25 \mathrm{~cm}^{2}$ flasks in a BOD type incubator at $37^{\circ} \mathrm{C}$. Under these conditions, the cell cycle time was approximately $12 \mathrm{~h}$ for CHO-k1 and $24 \mathrm{~h}$ for HTC.

The cells were grown for a complete cell cycle before treatments. The treatments performed were: a. untreated control; b. EMS $(155 \mu \mathrm{g} / \mathrm{ml})$; c. ME $(50 \mu \mathrm{g} / \mathrm{ml}) ;$ d. HE $(50 \mu \mathrm{g} / \mathrm{ml})$, e. BE $(50 \mu \mathrm{g} / \mathrm{ml}) ; \mathrm{f}$. AE $(0.75 \%)$; g. ME pre-incubated with EMS $(1 \mathrm{~h}) ; \mathrm{h}$. HE pre-incubated with EMS (1 h), k. ME combined with EMS; 1. HE combined with EMS; m. BE combined with EMS; n. AE combined with EMS. Combined treatments were simultaneous for $3 \mathrm{~h}$ (Tice et al. 2000), with and without $1 \mathrm{~h}$ pre-incubation with extract. Treatments were carried out in DMEM/F-12 medium 
(Gibco), in the absence of FBS. Each treatment was conducted in 3 separate experiments.

Single cell gel electrophoresis test-comet assay

The comet assay was performed according to the protocol of Tice et al. (2000), wich is based on the original works of Singh et al. (1988) and Klaude et al. (1996) included modifications introduced by Speit and Hartmann (1999).

After the treatment period, the cells were trypsinized, centrifuged and resuspended in culture medium. The cell suspension $(20 \mu \mathrm{l})$ was mixed with $0.5 \%$ low-melting point (LMP) agarose $(120 \mu \mathrm{l})$ at $37^{\circ} \mathrm{C}$, and distributed on microscope slides, pre-gelatinized with $1.5 \%$ normal agarose. The slides were covered and kept at $4^{\circ} \mathrm{C}$ for $20 \mathrm{~min}$. Afterward, the coverslips were removed and the slides were immersed in lysis solution [89.9 $\mathrm{ml}(2.5 \mathrm{M} \mathrm{NaCl}, 100 \mathrm{mM}$ EDTA, $10 \mathrm{mM}$ Tris, $\mathrm{pH}$ 10) $+1 \mathrm{ml}$ Triton $\mathrm{X}-100+10 \mathrm{ml} \mathrm{DMSO}$ ] for $1 \mathrm{~h}$ at $4{ }^{\circ} \mathrm{C}$, protected from light. After lysis, the slides were placed in an electrophoresis chamber, immersed in buffer $(300 \mathrm{mM} \mathrm{NaOH}$ plus $1 \mathrm{mM}$ EDTA, prepared from a stock solution of $10 \mathrm{~N} \mathrm{NaOH}-200 \mathrm{mM}$ EDTA, $\mathrm{pH} 10.0), \mathrm{pH}>13$, at $4^{\circ} \mathrm{C}$ for 20 min to denature DNA.

Electrophoresis was at $4{ }^{\circ} \mathrm{C}$ for $20 \mathrm{~min}$, at $25 \mathrm{~V}$ and $300 \mathrm{~mA}(1.6 \mathrm{~V} / \mathrm{cm})$. Afterward, the slides were neutralized with buffer $(0.4 \mathrm{M}$ Tris- $\mathrm{HCl})$ for $15 \mathrm{~min}(3-5 \mathrm{~min}$ washes $)$, dried, fixed in $100 \%$ ethanol for $10 \mathrm{~min}$, and stored until analysis.

\section{Analysis of slides and statistical}

On the day of analysis, slides were stained with $100 \mu \mathrm{l}$ of $200 \mu \mathrm{g} / \mathrm{ml}$ ethidium bromide and coverslipped. The slides were analyzed with a fluorescence microscope at 40X, with a $420-490 \mathrm{~nm}$ excitation filter and a $520 \mathrm{~nm}$ emission filter. A total of 100 cells were examined (Kobayashi et al. $1995)$ per treatment for each repetition. DNA fragmentation was classified as follows: class 0, absence of tail; class 1, tail with length up to the diameter of the comet head; class 2, tail with length of up to 2 times the diameter of the head; class 3, long tail with a length more than 2 times the diameter of the head, (Fig. 1) (Kobayashi et al. 1995). Apoptotic cells and necrotic cells were not evaluated (Tice et al. 2000). Several investigators have concluded that based on the characteristic appearance of the comets, apoptotic cells can be readily distinguished from necrotic cells in the alkaline SCGE (Olive et al. 1993, Fairbain et al. 1996). Apoptotic cells were concluded to form comets with large fan-like tails and small heads (i.e. so-called hedgehogs), while necrotic cells were concluded to form comets with relatively large heads and narrow tails of varying lengths (i.e., comets indistinguishable from those resulting from genotoxic damage) (Tice et al. 2000).

Statistical analysis of the data was performed with Student's $t$-test, wich is based on the individual culture response (Tice et al. 2000).

A

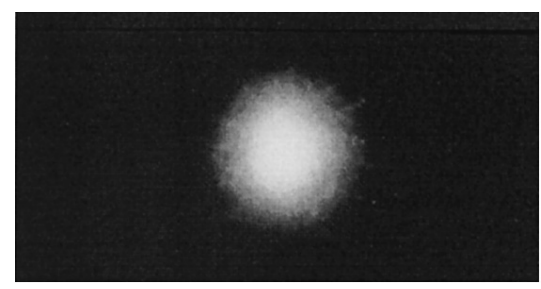

B

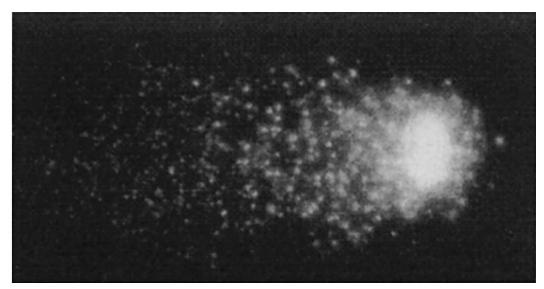

Fig. 1. Comet cells. A) cell without damage; B) cell with damage. 
Table 1. Frequency of damaged cells determined by the comet assay in genotoxicity test of Agaricus blazei (Ab) extracts, strain 99/26, in CHO-k1 cells

\begin{tabular}{|c|c|c|c|c|c|c|}
\hline \multirow{2}{*}{ Treatments } & \multirow{2}{*}{$\begin{array}{c}\text { Total } \\
\text { damaged cells }{ }^{3} \\
(\text { Mean } \pm \text { SD })\end{array}$} & \multicolumn{4}{|c|}{ Class (Mean) } & \multirow{2}{*}{$\begin{array}{c}\text { Score } \\
\text { (Mean) }\end{array}$} \\
\hline & & 0 & 1 & 2 & 3 & \\
\hline Control & $7 \pm 2.6$ & 93 & 5.3 & 1 & 0.67 & 9.3 \\
\hline EMS $^{1}$ & $96.6 \pm 3.2 *$ & 3.3 & 23 & 46 & 27.7 & $198^{*}$ \\
\hline $\mathrm{ME}^{2}$ & $36 \pm 18.4 *$ & 64 & 22 & 9.3 & 4.7 & $54.7 *$ \\
\hline $\mathrm{HE}^{2}$ & $55 \pm 23.8 *$ & 45 & 37.3 & 13.3 & 4.3 & $77 *$ \\
\hline $\mathrm{BE}^{2}$ & $44.7 \pm 14.9^{*}$ & 55.3 & 33.7 & 10 & 1.7 & $56.7^{*}$ \\
\hline $\mathrm{AE}^{2}$ & $60.6 \pm 13.2 *$ & 39.3 & 47.3 & 11.3 & 2 & $76^{*}$ \\
\hline
\end{tabular}

${ }^{1}$ EMS: Ethylmethane sulfonate, $155 \mu \mathrm{g} / \mathrm{ml} .{ }^{2}$ Agaricus blazei extracts (ME: methanol extract (50 $\left.\mu \mathrm{g} / \mathrm{ml}\right)$; HE: hexane extract $(50 \mu \mathrm{g} / \mathrm{ml})$; BE: $n$-butanol extract $(50 \mu \mathrm{g} / \mathrm{ml})$; AE: aqueous extract $(0.75 \%) .{ }^{3}$ Total cells with damage for each treatment, out of 300 cells examined; SD: standard deviation; Student's $t$-test $(0.05>p<0.001)$, treatments followed by

* differ statistically from control. Class and score: see in text.

Table 2. Frequency of damaged cells determined by the comet assay in genotoxicity test of Agaricus blazei (Ab) extracts, strain 99/26, in HTC cells

\begin{tabular}{|c|c|c|c|c|c|c|}
\hline \multirow{2}{*}{ Treatments } & \multirow{2}{*}{$\begin{array}{c}\text { Total } \\
\text { damaged cells }{ }^{3} \\
(\text { Mean } \pm S D)\end{array}$} & \multicolumn{4}{|c|}{ Class (Mean) } & \multirow{2}{*}{$\begin{array}{c}\text { Score } \\
\text { (Mean) }\end{array}$} \\
\hline & & 0 & 1 & 2 & 3 & \\
\hline Control & $6.7 \pm 4.6$ & 93.3 & 6 & 0.3 & 0.3 & 7.7 \\
\hline $\mathrm{EMS}^{1}$ & $95 \pm 2.6^{*}$ & 5 & 57.7 & 25 & 12.3 & $144.7 *$ \\
\hline $\mathrm{ME}^{2}$ & $22 \pm 14$ & 78 & 19 & 1 & 2 & 27 \\
\hline $\mathrm{HE}^{2}$ & $35 \pm 29.7$ & 65 & 28 & 4 & 3 & 29 \\
\hline $\mathrm{BE}^{2}$ & $37.3 \pm 21.5$ & 62.7 & 30 & 2.7 & 4.7 & 45 \\
\hline $\mathrm{AE}^{2}$ & $46 \pm 43.8$ & 54 & 27 & 12 & 7 & 72 \\
\hline
\end{tabular}

${ }^{1}$ EMS: Ethylmethane sulfonate, $155 \mu \mathrm{g} / \mathrm{ml} .{ }^{2}$ Agaricus blazei extracts (ME: methanol extract ( $\left.50 \mu \mathrm{g} / \mathrm{ml}\right)$; HE: hexane extract $(50 \mu \mathrm{g} / \mathrm{ml})$; BE: $n$-butanol extract $(50 \mu \mathrm{g} / \mathrm{ml})$; AE: aqueous extract $(0.75 \%)) .{ }^{3}$ Total cells with damage for each treatment, out of 300 cells examined; SD: standard deviation; Student's $t$-test $(p<0.001)$, treatments followed by

* differ statistically from control.

\section{Results}

Tables 1 and 2 present the data on the Ab extracts genotoxicity in CHO-k1 and HTC cells, respectively, as the number of cells found in each class of damage and the respective score for each treatment. Tables 3 and 4 show the antigenotoxicity data in CHO-k1 and HTC, respectively. The findings in Table 1 indicate that the extracts showed genotoxicity in CHO-k1 cells, while a genotoxic effect was not seen in HTC cells (Table 2).

Tables 3 and 4 show that there was no statistically significant difference between treatments with extracts and that with EMS, indicating that the methanolic, hexanic, $n$-butanolic and aqueous extracts had no antigenotoxic properties in both exposure conditions tested, simultaneous and simultaneous with pre-incubation, and in both CHO-k1 and HTC cells.

\section{Discussion}

Many substances have been considered antimutagenic or anticarcinogenic, while also having 
Table 3. Frequency of damaged cells determined by the comet assay in antigenotoxicity test of Agaricus blazei (Ab) extracts, strain 99/26, in CHO-k1 cells

\begin{tabular}{|c|c|c|c|c|c|c|}
\hline \multirow{2}{*}{ Treatments } & \multirow{2}{*}{$\begin{array}{c}\text { Total } \\
\text { damaged cells }{ }^{3} \\
(\text { Mean } \pm \text { SD })\end{array}$} & \multicolumn{4}{|c|}{ Class (Mean) } & \multirow{2}{*}{$\begin{array}{c}\text { Score } \\
\text { (Mean) }\end{array}$} \\
\hline & & 0 & 1 & 2 & 3 & \\
\hline Control & $7 \pm 2.6^{*}$ & 93 & 5.3 & 1 & 0.67 & 9.3 \\
\hline $\mathrm{EMS}^{1}$ & $96.6 \pm 3.2$ & 3.3 & 23 & 46 & 27.7 & $198^{*}$ \\
\hline \multicolumn{7}{|c|}{ Antigenotoxicity } \\
\hline $\mathrm{ME}^{2}$ & $88.7 \pm 11.4$ & 11.3 & 31.7 & 22.3 & 34.7 & 180.3 \\
\hline $\mathrm{HE}^{2}$ & $97.3 \pm 3.8$ & 2.7 & 33.7 & 18.3 & 45.3 & 206.3 \\
\hline $\mathrm{BE}^{2}$ & $95.3 \pm 4.7$ & 4.3 & 37.7 & 27 & 22 & 157.7 \\
\hline $\mathrm{AE}^{2}$ & $93 \pm 10.4$ & 7 & 61.7 & 24 & 7.3 & 131.7 \\
\hline \multicolumn{7}{|c|}{ Antigenotoxicity with pre-incubation $(1 \mathrm{~h})$} \\
\hline $\mathrm{ME}^{2}$ & $95.6 \pm 5.8$ & 4.3 & 35 & 43.7 & 17 & 173.3 \\
\hline $\mathrm{HE}^{2}$ & $93 \pm 5.68$ & 7 & 37.3 & 36.3 & 19.3 & 168 \\
\hline $\mathrm{BE}^{2}$ & $91.7 \pm 14.4$ & 8.3 & 29 & 35 & 27.7 & 189 \\
\hline $\mathrm{AE}^{2}$ & $91 \pm 11.5$ & 9 & 39.3 & 23.7 & 28 & 170.7 \\
\hline
\end{tabular}

${ }^{1}$ EMS: Ethylmethane sulfonate, $155 \mu \mathrm{g} / \mathrm{ml} .{ }^{2}$ Agaricus blazei extracts (ME: methanol extract ( $\left.50 \mu \mathrm{g} / \mathrm{ml}\right)$; HE: hexane extract $(50 \mu \mathrm{g} / \mathrm{ml})$; BE: $n$-butanol extract $(50 \mu \mathrm{g} / \mathrm{ml})$; AE: aqueous extract $(0.75 \%)) .{ }^{3}$ Total cells with damage for each treatment, our of 300 cells examined; SD: standard deviation; Student's $t$-test $(0.05>p<0.001)$, treatments followed by

* differ statistically from control.

Table 4. Frequency of damaged cells determined by the comet assay in antigenotoxicity test of Agaricus blazei (Ab) extracts, strain 99/26, in HTC cells

\begin{tabular}{|c|c|c|c|c|c|c|}
\hline \multirow{2}{*}{ Treatments } & \multirow{2}{*}{$\begin{array}{c}\text { Total } \\
\text { damaged cells }^{3} \\
(\text { Mean } \pm S D)\end{array}$} & \multicolumn{4}{|c|}{ Class (Mean) } & \multirow{2}{*}{$\begin{array}{c}\text { Score } \\
\text { (Mean) }\end{array}$} \\
\hline & & 0 & 1 & 2 & 3 & \\
\hline Control & $6.7 \pm 4.6$ & 93.3 & 6 & 0.3 & 0.3 & 7.7 \\
\hline $\mathrm{EMS}^{1}$ & $95 \pm 2.6^{*}$ & 5 & 57.7 & 25 & 12.3 & $144.7 *$ \\
\hline \multicolumn{7}{|c|}{ Antigenotoxicity } \\
\hline $\mathrm{ME}^{2}$ & $87.7 \pm 9$ & 12.3 & 65 & 20 & 2.7 & 113 \\
\hline $\mathrm{HE}^{2}$ & $92.5 \pm 7.8$ & 7.5 & 69 & 20 & 3.5 & 79.6 \\
\hline $\mathrm{BE}^{2}$ & $99 \pm 1.7$ & 1 & 39 & 16.3 & 36 & 194.3 \\
\hline $\mathrm{AE}^{2}$ & $98.7 \pm 2.3$ & 1.3 & 39.3 & 20.6 & 38.7 & 196.6 \\
\hline \multicolumn{7}{|c|}{ Antigenotoxicity with pre-incubation ( $1 \mathrm{~h}$ ) } \\
\hline $\mathrm{ME}^{2}$ & $99.7 \pm 0.6$ & 0.3 & 23.3 & 33.7 & 42.6 & 218.6 \\
\hline $\mathrm{HE}^{2}$ & $100 \pm 0$ & 0 & 74.5 & 22.5 & 3 & 85.7 \\
\hline $\mathrm{BE}^{2}$ & $99 \pm 1.7$ & 1 & 58.7 & 28.7 & 11.7 & 151 \\
\hline $\mathrm{AE}^{2}$ & $99 \pm 1$ & 1 & 33 & 23.7 & 20.3 & 163.3 \\
\hline
\end{tabular}

${ }^{1}$ EMS: Ethylmethane sulfonate, $155 \mu \mathrm{g} / \mathrm{ml} .{ }^{2}$ Agaricus blazei extracts (ME: methanol extract (50 $\left.\mu \mathrm{g} / \mathrm{ml}\right)$; HE: hexane extract $(50 \mu \mathrm{g} / \mathrm{ml})$; BE: $n$-butanol extract $(50 \mu \mathrm{g} / \mathrm{ml})$; AE: aqueous extract $(0.75 \%))$. ${ }^{3}$ Total cells with damage for each treatment, our of 300 cells examined; SD: standard deviation; Student's $t$-test $(p<0.001)$, treatments followed by $*$ differ statistically from control.

mutagenic or carcinogenic properties (Zeiger 2003). Dashwood (2002) noted that components of the daily diet can show mutagenic as well as protective effects, since the type of effect observed depends on the test system used (Waters et al. 1990).

Geographic, climatic and intra-species variations can interfere with biological response. Other factors, such as methods for the collection and storage of the mushrooms, can lead to the loss or degradation of the active compounds (Chang 1996). 
Menoli et al. (2001) demonstrated desmutagenic activity for an aqueous Ab extract using the comet assay, while a bio-antimutagenic effect was seen with $\mathrm{Ab}$ extracts according to the micronucleus test (Oliveira et al. 2002) and presence of chromosomal aberrations (Luiz et al. 2003a). In the present study, we did not observe any antigenotoxic activity for Ab extracts using the comet assay in both CHO-k1 and HTC cells, as did Guterrez et al. (2004) for different aqueous Ab extracts in V79 cells. However, the presence of antigenotoxic potential for Ab should not be excluded, since other authors have seen a protective effect of aqueous $\mathrm{Ab}$ extracts using the comet assay (Menoli et al. 2001, Oliveira et al. 2002), micronucleus test (Guterrez et al. 2004) and test for chromosomal aberrations (Bellini et al. 2003) in vitro. The protective effect of aqueous Ab extracts was also demonstrated in vivo against clastogenic activity of cyclophosphamide (Delmanto et al. 2001).

The genotoxic potential of different aqueous $\mathrm{Ab}$ extracts was not observed by Guterrez et al. (2004) and Luiz et al. (2003b). However, it is not observed genotixicity with methanolic, hexanic and $n$-butanolic extracts in CHO-k1, and only the aqueous extract in HTC. These results suggest that there is a significant difference in the genotoxicity of $\mathrm{Ab}$ extracts in the presence or absence of metabolism, indicating that when component of the extracts are metabolized, the biotransformed compounds produced are not toxic to DNA.

Our results are in contrast with some findings in the literature (Menoli et al. 2001, Oliveira et al. 2002, Bellini et al. 2003, Luiz et al. 2003a, Guterrez et al. 2004), which could be due to the variation in biochemical composition among $\mathrm{Ab}$ strains and due to the higher concentrations and longer times of treatment used in other studies. Differences could also be explained by the fact that testing for antimutagenic activity against specific chemical agents and test systems is not sufficient for arriving at a precise conclusion on the activity type of the substance tested and whether its activity would be the same in different systems (Zeiger 2003).

All these findings lead us to conclude that investigations of the Sun Mushroom are still in the early stages with regard to its biological activity and its interaction with cell physiology processes.

\section{Acknowledgments}

We thank CAPES, CNPq and Fundação Araucária by financial support. We also thank Dr. A. Leyva for his help in the preparation of the manuscript.

\section{References}

Bellini, M. F., Giacomini, N. L., Eira, A. F., Ribeiro, L. R. and Mantovani, M. S. 2003. Anticlastogenic effect of aqueous extracts of Agaricus blazei on CHO-k1 cells, studying different developmental phases of the mushroom. Toxicology In Vitro 17: 465-469.

Chang, R. 1996. Functional properties of edible mushrooms. Nutrition Rev. 54: 91-93.

Dashwood, R. H. 2002. Modulation of heterocyclic amine-induced mutagenicity and carcinogenicity: an 'A-to-Z' guide to chemopreventive agents, promoters, and transgenic models. Mutat. Res. 511: 89-112.

Delmanto, R. D., Lima, P. L. A., Suguia, M. M., Salvadori, D. M. F., Da Eira, A. F., Speit, G. and Ribeiro, L. R. 2001. Antimutagenic effect of Agaricus blazei Murrill mushroom on the genotoxicity induced by cyclophosphamide. Mutat. Res. 496: 15-21.

Fairbain, J. J., Khan, M. W., Ward, K. J., Loveridge, B. W., Fairbain, D. W. and O’Neill, K. L. 1995. Induction of apoptotic cell DNA fragmentation in human cells after treatment with hyperthermia. Cancer Letters 89: 183-188.

Guterrez, Z. R., Mantovani, M. S., Eira, A. F., Ribeiro, L. R. and Jordão, B. Q. 2004. Variation of the antimutagenicity effects of water extracts of Agaricus blazei Murrill in vitro. Toxicology In Vitro 18: 301-309.

Klaude, M., Eriksson, S., Nygren, J. and Ahnström, G. 1996. The comet assay: mechanisms and technical considerations. Mutat. Res. 363: 89-96.

Kobayashi, H., Sugiyama, C., Morikawa, Y., Hayashi, M. and Sofuni, T. 1995. A comparison between manual microscopic analysis and computerized image analysis in the single cell gel electrophoresis assay. MMS Commun. 3: $103-115$.

Luiz, R. C., Jordão, B. Q., Eira, A. F., Ribeiro, L. R. and Mantovani, M. S. 2003a. Mechanism of anticlastogenicity of Agaricus blazei Murrill mushroom organic extracts in wild type $\mathrm{CHO}(\mathrm{k} 1)$ and repair deficient (xrs5) cells by chromo- 
some aberration and sister chromatid exchange assays. Mutat. Res. 528: 75-79.

—, - , - and - 2003b. Non-mutagenic or genotoxic effects of medicinal aqueous extracts from the Agaricus blazei mushroom in V79 cells. Cytologia 68: 1-6.

Machado, P. M., Rodrigues-Filho, E., Terezan, A. P., Ribeiro, L. R. and Mantovani, M. S. 2005. Cytotoxicity, genotoxicity and antimutagenicity of hexane extracts of Agaricus blazei determined in vitro by the comet assay and CHO/HGPRT gene mutation assay. Toxicology In Vitro 19: 533-539.

Menoli, R. C. N., Mantovani, M. S., Ribeiro, L. R., Speit, G. and Jordão, B. Q. 2001. Antimutagenic effects of the mushroom Agaricus blazei Murill extracts on V79 cells. Mutat. Res. 496: 5-13.

Mizuno, T. 1995a. Bioactive biomolecules of mushrooms - food, function and medicinal effect of mushroom fungi. Food Rev. Int. 11: 7-21.

Mizuno, T. K. 1995b. Agaricus blazei Murill: Medicinal and Dietary Effects. Food Reviews International 11: 167-172.

Olive, P. L., Frazer, G. and Banath, J. P. 1993. Radiation-induced apoptosis measured in TK6 human B lymphoblast cells using the comet assay. Radiat. Res. 136: 130-136.

Oliveira, J. M., Jordão, B. Q., Ribeiro, L. R., Eira, A. F. and Mantovani, M. S. 2002. Anti-genotoxic effect of aqueous extracts of sun mushroom (Agaricus blazei Murill lineage 99/26) in mammalian cells in vitro. Food and Chemical Toxicology 40: 15-20.

Singh, N. P., Mccoy, M. T., Tice, R. R. and Schneider, E. L. 1988. A simple technique for quantitation of low levels of DNA damage in individual cells. Exper. Cell Res. 175: 184-191.

Speit, G. and Hartmann, A. 1999. The comet assay (single-cell gel test). A sensitive genotoxicity test for the detection of DNA damage and repair. In: Henderson, D. S. (ed.). Methods in Molecular Biology: DNA Repair Protocols-Eukaryotic Systems. Totowa: Humana Press 113: 203-211.

Takeda, Y., Togashi, H., Shinzawa, H., Miyano, S., Ishii, R., Karasawa, T., Takeda, Y., Saito, T., Saito, K., Haga, H., Matsuo, T., Aoki, M., Mitsuhashi, H., Watanabe, H. and Takahashi, T. 2000. Spontaneous regression of hepatocellular carcinoma and review of literature. J. Gastroenterology and Hepatology 15: 1079-1086.

Tice, R. R., Agurell, E., Anderson, D., Burlinson, B., Hartmann, A., Kobayashi, H., Miyamae, Y., Rojas, E., Ryu, J. C. and Sasaki Y. F. 2000. Single Cell Gel/Comet Assay: Guidelines for In Vitro and In Vivo Genetic Toxicology Testing. Enviro. and Mol. Mutagenesis 35: 206-221.

Wasser, S. P., Didukh, M. Y., Amazonas, M. A. L. A., Nevo, E., Staments, P. and Eira, A. F. 2002. Is a widely cultivated culinary-medicinal Royal Sun Agaricus (the Himematsutake mushroom) indeed Agaricus blazei Murrill? Int. J. Med. Mush. 4: 267-290.

Waters, M. D., Brady, A. L., Stack, H. F. and Brockman, H. E. 1990. Antimutagenicity profiles for some model compounds. Mutat. Res. 238: 57-85.

Zeiger, E. 2003. Illusions of safety: antimutagens can be mutagens, and anticarcinogens can be carcinogens. Mutat. Res. 546: 191-194. 